\title{
External morphology of the immature stages of Neotropical heliconians: VIII. Philaethria wernickei (Röber) (Lepidoptera, Nymphalidae, Heliconiinae)
}

\author{
Kim R. Barão $0^{1,2}$ \& Gilson R. P. Moreira ${ }^{1,3}$
}

${ }^{1}$ Departamento de Zoologia, Instituto de Biociências, Universidade Federal do Rio Grande do Sul, Avenida Bento Gonçalves, 9500, 91501-970 Porto AlegreRS, Brazil.

${ }^{2}$ Fellowship CAPES. kbarao@yahoo.com.br

${ }^{3}$ Fellowship CNPq. gilson.moreira@ufrgs.br

\begin{abstract}
External morphology of the immature stages of Neotropical heliconians: VIII. Philaethria wernickei (Röber) (Lepidoptera, Nymphalidae, Heliconiinae). The external features of egg, larva, and pupa of Philaethria wernickei (Röber, 1906) are described and illustrated, based upon light and scanning electron microscopy.

KEYWORDS. Egg; emerald butterfly; heliconians; larva; pupa.

RESUMO. Morfologia externa dos estágios imaturos de heliconíneos neotropicais: VIII. Philaethria wernickei (Röber) (Lepidoptera, Nymphalidae, Heliconiinae). As estruturas externas do ovo, larva e pupa de Philaethria wernickei (Röber, 1906) são descritas e ilustradas, baseadas em microscopia ótica e eletrônica de varredura.
\end{abstract}

PALAVRAS-CHAVE. Borboleta esmeralda; heliconíneos; larva; ovo; pupa.

According to Lamas (2004), currently seven species are assigned to the genus Philaethria Billberg, 1820: P. dido (Linnaeus, 1763), P. ostara (Röber, 1906), P. wernickei (Röber, 1906), P. diatonica (Fruhstorfer, 1912), P. pygmalion (Fruhstorfer, 1912), P. constantinoi Salazar, 1991, and P. andrei Brévignon, 2002. Philaethria dido is widely distributed in the Neotropical region (Benson et al. 1975); P. ostara, $P$. diatonica, . pygmalion, $P$. constantinoi, and $P$. andrei have distributions restricted to northern South America and Central America (Salazar 1991; Constantino 1999; Brévignon 2002); and $P$. wernickei is found in the south, southeast and northeast regions of Brazil (Suomalainen \& Brown 1984; Constantino 1999).

The genus, however, needs revision, and $P$. dido may in fact represent a species complex (Brown 1981). Among phylogenies proposed for heliconians until now (e.g., Emsley 1963; Brown 1981; Brower 1994; Penz 1999; Beltrán et al. 2007), there is no consensus about the phylogenetic position of Philaethria in relation to the other genera. Although the genus is considered monophyletic, the morphological characters currently available are insufficient to reveal the relationships among its species (Penz 1999). The little information available about the morphology of the immature stages for this genus is limited to populations of $P$. dido from Trinidad and Tobago (Beebe et al. 1960; Fleming 1960) and Costa Rica (Young 1974). Our preliminary observations suggested that characters of interspecific differentiation compiled by Brown \& Mielke (1972) and Brown (1981) are not stable at a particular locality in southern Brazil, and overlap with those attributed to sympatric populations of $P$. dido. We are unaware of the existence of information related to the external tegumentary ultrastructure of Philaethria, except for the report by Dell'Erba et al. (2005) for the egg. Information related to the oviposition behavior and the development time of $P$. dido in the laboratory was provided by Young (1974).

The target species of the present study, popularly known as "emerald butterfly" (Biezanko \& Link 1972), was originally described by Röber (1906) as Metamorpha wernickei, based on adult material collected in the states of Rio Grande do Sul (RS) and Santa Catarina, Brazil. Seitz (1913) treated it as a subspecies of Philaethria dido (Linnaeus, 1758). Brown \& Mielke (1972) revalidated the species, distinguishing it from $P$. dido, based on morphological characters of the male genitalia and on the ventral colour pattern of the posterior wings.

In RS, P. wernickei is found in low densities, mainly in open forests. It has a solitary habit, reaches a considerable height when flying, and lays eggs preferentially on passion vines of high leaf mass (Benson et al. 1975; Brown 1981; Dell'Erba et al. 2005). In general, the oviposition occurs on the upper or lower side of old leaves and on dry or green tendrils (Dell'Erba et al. 2005). In southeastern Brazil, Passiflora caerulea Linnaeus, P. mansii (C. Martius), and $P$. sidaefolia (M. Roemer) are used as larval host plants (Brown $\&$ Mielke 1972). In RS, oviposition was recorded on P. actinia Hooker, $P$. caerulea, $P$. edulis Sims, $P$. elegans Masters, and P. suberosa Linnaeus (Brown \& Mielke 1972; Dell'Erba et al. 2005). Ongoing studies in our laboratory have indicated a high frequency of $P$. wernickei in the dense and mixed ombrophilous forests that occur in northeastern RS, where the 
larvae are generally found on $P$. actinia. However, there are no intensive studies focusing on the biology, behavior, and/ or ecology of the immature stages; the scattered information related to these topics comes from occasional observations made during extensive field studies (e.g., Brown \& Mielke 1972; Benson et al. 1975; Brown 1981; Dell'Erba et al. 2005).

The present paper continues the series of studies on the morphology of Neotropical heliconians (see Silva et al. 2008), describing for the first time in detail the immature stages of $P$. wernickei, establishing a basis for ongoing studies on the phylogeography of this species, and on the taxonomy and phylogeny of the genus Philaethria.

\section{MATERIAL AND METHODS}

Single laid eggs and larvae were collected from leaves of $P$. actinia plants located in the municipalities of Maquiné, São Francisco de Paula, and Viamão, RS. Eggs were placed on moist filter paper in Petri dishes, until hatching. After hatching, the larvae were grown individually on branches of $P$. actinia, kept in plastic bottles with a wire support. The bottles were filled with tap water, covered with a fine mesh, and kept under laboratory conditions $\left(25 \pm 1^{\circ} \mathrm{C}, 14 \mathrm{~h}\right.$ light/ day). The larvae were inspected daily. Head capsules were collected after each ecdysis, fixed in Dietrich's fluid, and preserved in $70 \%$ ethanol. Additional eggs, larvae, and pupae were also fixed and preserved as previously described. The examined material (minimum of 10 per immature stage) was deposited in the collection of the Laboratório de Morfologia e Comportamento de Insetos (LMCI), of the Departamento de Zoologia, Universidade Federal do Rio Grande do Sul (UFRGS), city of Porto Alegre, Rio Grande do Sul, Brazil, under accession numbers 104, 115, 156, 157, 158, and 159 . Adult vouchers (five per locality) were also deposited in the tissue collection of LMCI, under the accession numbers 21 (Centro Politécnico, Curitiba, Paraná), 27 (Floresta Nacional, São Francisco de Paula, RS), and 43 (Gonco Soco, Caeté, Minas Gerais). The wings were detached and stored dry in envelopes; the thorax was immersed in absolute alcohol and kept frozen at $-20^{\circ} \mathrm{C}$; and the head, abdomen, and legs were fixed in Dietrich's fluid and preserved in $70 \%$ ethanol.

Aspects of the general morphology of the immature stages were analysed from material that was either fixed or embedded in glycerin jelly. Head capsules were hydrated, cleared in a $10 \%$ potassium hydroxide solution $(\mathrm{KOH})$, and slide-mounted in glycerin jelly. Drawings were made from fixed specimens, using a reticulated ocular attached to a Leica ${ }^{\circledR}$ M125 stereomicroscope. Water-colour paintings of the first and fifth instars and the pupa (Figs. 25-27) were based on photographs and live specimens. Tegumentary ultrastructure was studied at the Centro de Microscopia Eletrônica of UFRGS. For the analyses, the specimens were dehydrated in a Bal-tec ${ }^{\circledR}$ CPD030 critical-point dryer, mounted with double-sided tape on metal stubs, and coated with gold in a Bal-tec ${ }^{\circledR}$ SCD050 sputter coater. Specimens were examined and photographed in a JEOL $₫$ JSM5800 scanning electron microscope.
To distinguish larval stadia, the greatest width of the head capsule in frontal view was measured with a micrometer scale mounted in the ocular of the stereomicroscope. By using the least-squares method, the corresponding data were adjusted to the power function: $\mathrm{y}=\mathrm{ae}^{\wedge} \mathrm{bx}$ (Snedecor \& Cochran 1980).

For the egg, we used the nomenclature employed by Dell'Erba et al. (2005). Larval body areas were labelled according to Peterson (1962). For the primary chaetotaxy and crochet of prolegs, we followed Stehr (1987). The setae of the paraproct and anal prolegs were labelled according to Kitching (1984). To describe the scoli we followed Beebe et al. (1960), and for the nomenclature of the pupa, we used Mosher (1916).

\section{RESULTS AND DISCUSSION}

Egg (Figs. 1-5)

The egg is yellow throughout embryonic development (Brown 1981; Dell'Erba et al.2005), unlike the report of Beebe et al. (1960) for $P$. dido, where brown spots were observed at the end. The egg has a flat base and a slightly narrowed apex (Fig. 1). The mean ( \pm standard error, $n=10$ ) was $1.208 \pm 0.023$ $\mathrm{mm}$ for height and $1.39 \pm 0.016$ for diameter (Dell'Erba et al. 2005). The values for both height and diameter are larger than those obtained by Beebe et al. (1960) for P. dido.

The egg of $P$. wernickei differs from those of Agraulis Boisduval \& Le Conte, [1835], Dione Hübner, [1819], Dryadula Michener, 1942, Dryas Hübner, [1807], Eueides Hübner, 1816, and Heliconius Kluk, 1780, by the presence of unaligned horizontal (Hr) carinae (Dell'Erba et al. 2005).

Both horizontal $(\mathrm{Hr})$ and vertical $(\mathrm{Vr})$ carinae have smooth surfaces (Fig. 2). The vertical type varied $(n=10)$ in number between 19 and 22, and the horizontal, from 10 to 11. These values contrast with those obtained by Beebe et al. (1960) for P. dido, where 20 to 24 were found for $\mathrm{Vr}$, and 12 to 13 for Hr. The carinae have a slight longitudinal depression between the aeropyles (Ac) (Fig. 2). These are round, without an elevation in the peritreme, similar to those of the eggs of Agraulis vanillae maculosa (Stichel, [1908]), Dione juno juno (Cramer, 1779), and Dryadula phaetusa (Linnaeus, 1758) (Dell'Erba et al. 2005).

As in A. vanillae maculosa, D. juno juno, and D. phaetusa, the cells surrounded by the carinae have a smooth surface and round internal angles, different from those of Heliconius ethilla narcaea Godart, 1819, which have wrinkles (Dell'Erba et al. 2005). The upper cells (Uc) vary from tetragonal to hexagonal (Fig. 4), and the lower cells (Lc) are tetragonal (Fig. 5). The micropylar region (Fig. 3) is composed of the annulus and the rosette, and the micropyles are located in the centre of the latter (Mp) (Downey \& Allyn 1981). This micropylar region has a smooth flat surface, and it is not well defined in comparison to all the species cited above (Dell'Erba et al. 2005).

Larvae (Figs. 6-26)

The first instar (Fig. 25) head capsule is dark brown, fading to greyish in the region of the mouth and the antennae. This 

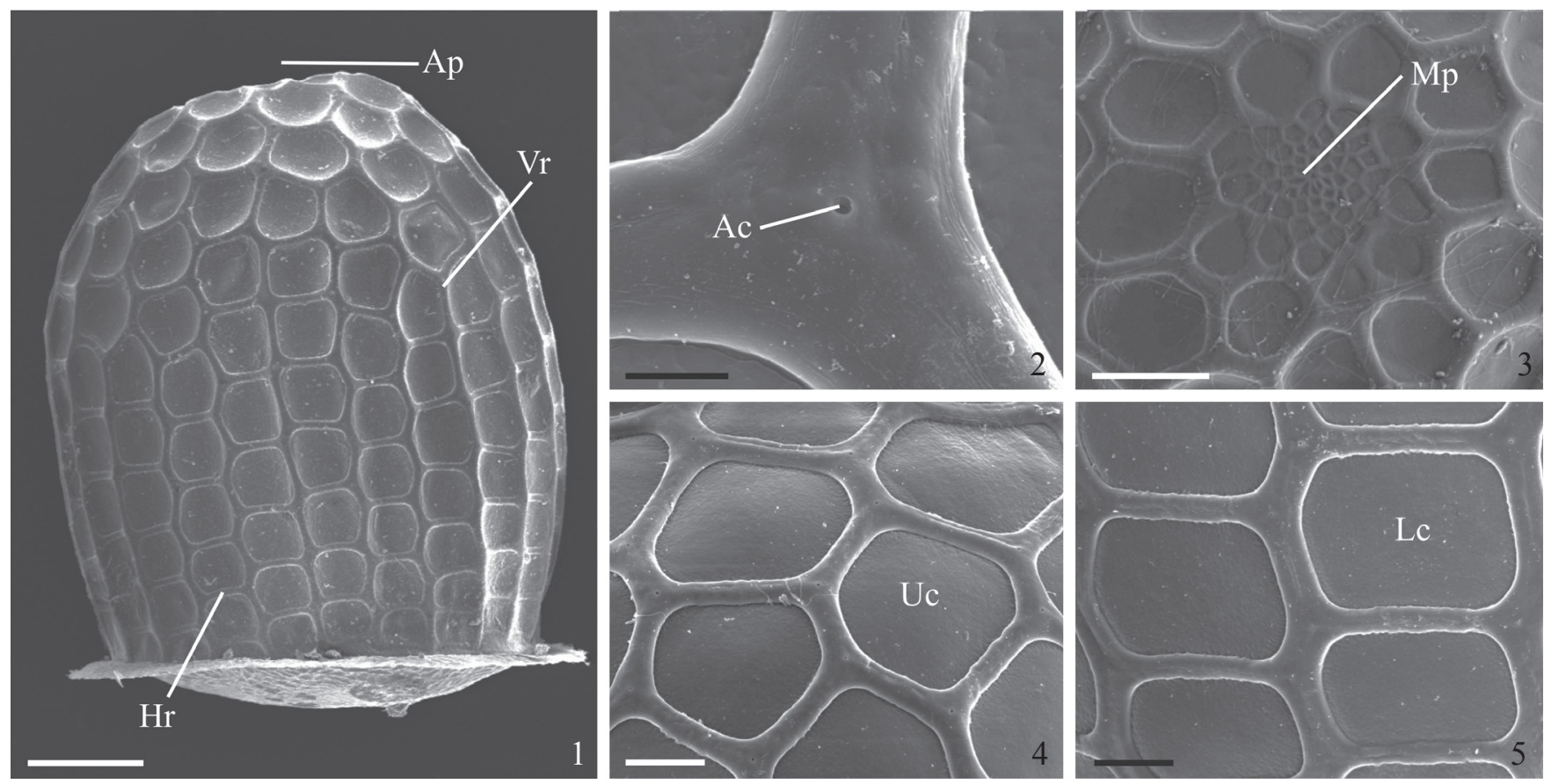

Figs. 1-5. Scanning electron micrographs of the egg of Philaethria wernickei (Röber, 1906). 1, lateral view; 2, aeropyle; 3, micropylar region; 4, upper cells; 5, lower cells. Ac, aeropyle; Ap, anterior pole; Hr, horizontal carina; Lc, lower cell; Mp, micropyles; Uc, upper cell; Vr, vertical carina. Bars $=200$, 10, 100, 50 , and $50 \mu \mathrm{m}$, respectively. Modified from Dell'Erba et al. (2005).

colouration contrasts with that of $P$. dido, which, according to Beebe et al. (1960), has a transparent, brownish-orange head. The body is yellowish upon hatching, and soon becomes greenish due to the colour of the intestinal contents once the larva begins eating. The prothorax (T1) has two whitish spots: one posterior to the subdorsal (SD) and lateral (L) setae, and the other posterior to the lateral and subventral setae (SV). On the other segments, white spots are arranged in three series: the first, among the clusters of dorsal (D) and subdorsal setae in $\mathrm{T} 2$ and $\mathrm{T} 3$, and on abdominal segments (AB) 2, 4, 6, and 8 ; the second, among the dorsal and lateral setae in $\mathrm{T} 2$ and on all $\mathrm{AB}$ segments; however, on segments $\mathrm{AB} 1, \mathrm{AB} 3, \mathrm{AB} 5$, and $\mathrm{AB} 7$ the spots are yellowish; the third series is present on all abdominal segments, among the lateral setae, with the spots on segments $\mathrm{AB} 1, \mathrm{AB} 3, \mathrm{AB} 5$, and $\mathrm{AB} 7$ also yellowish. The second and third series of spots are different from $P$. dido, in which the second group of spots occurs on $\mathrm{T} 2, \mathrm{~T} 3, \mathrm{AB} 2, \mathrm{AB} 4$, $\mathrm{AB} 6, \mathrm{AB} 8$, and $\mathrm{AB} 10$, and the third on $\mathrm{T} 1, \mathrm{AB} 2, \mathrm{AB} 4, \mathrm{AB} 6$, $\mathrm{AB} 8$, and $\mathrm{AB} 10$ (Beebe et al. 1960). The median portions of abdominal segments $1,3,5$, and 7 have an ochre-coloured band that usually extends from the dorsal to the lateral region, but that may be restricted to the upper half of the last segment (AB7). These characteristics are shared with $P$. dido (Beebe et al. 1960). The body setae are black with a colourless apex; the prothoracic, anal plates and the bases of the chalazae are brown; the thoracic legs and the bases of the prolegs are also brown.

The second instar general body colouration is brown, and the pattern of ochre bands is as described for the first instar. The orange spots are restricted to the bases of the dorsal and supraspiracular scoli of segments AB2, AB4, AB6, and AB8; the scoli are black at the base. The third and fourth instars are similar in colour to the fifth instar.

The fifth instar has a yellowish brown head (Fig. 26), with the stemmatal and mandibular regions black; the bases of the head scoli are also black. The background body colouration is yellow-green. Each body segment has three black bands: one anterior to the scoli, and two posterior to them. Beebe et al. (1960) reported four vertical black bands for P. dido. $\mathrm{AB} 1$ to $\mathrm{AB} 9$ each has a mid-dorsal black spot between the dorsal scoli. From AB1 to AB8, the bases of the dorsal and supraspiracular scoli, and also the area in between them are orange. These differ from $P$. dido (Beebe et al. 1960), where orange areas are found only between the scoli of $\mathrm{AB} 1, \mathrm{AB} 3$, $\mathrm{AB} 5$, and $\mathrm{AB} 7 . \mathrm{AB} 9$ has a black band in the anterior region, which extends dorso-laterally to lateral scoli; a grey stripe is present on the margin of the anal plate. $10 \mathrm{AB}$ has a greyish anal plate. The dorsal, supraspiracular, and anal scoli show a colour gradient that varies from orange at the base to black on the apex; the subspiracular scoli are yellow at the base and black on the apex, a pattern also reported for $P$. dido by Beebe et al. (1960). The legs are brown with dark-purple coxae, the prolegs are yellow, and the spiracles are black.

The head capsule and mouth appendages of the first instar (Figs. 6, 10-13) follow the generic pattern found in Lepidoptera (Stehr 1987). The front and clypeus are fused, with an indistinct frontoclypeal suture. The anticlypeus is pronounced, linking the frontoclypeus to the bilobed labrum, which partly covers the mandibles in frontal view. The antennae are inserted in an eversible membranous antacoria located laterally to the mandibles. The antocoria resembles that of H. erato phyllis (Fabricius, 1775) in the absence of 

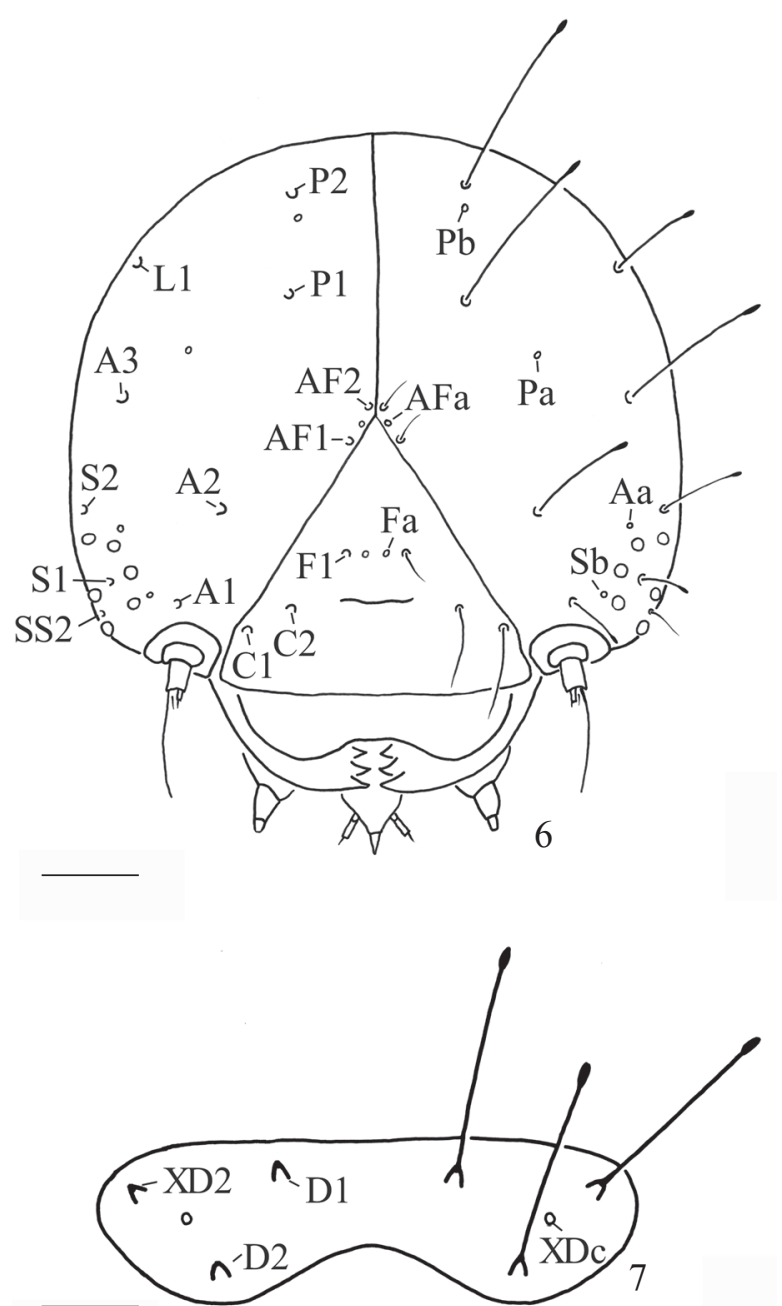

Figs. 6-7. Head capsule and prothoracic plate of the first-instar larva of Philaethria wernickei (Röber, 1906). 6, frontal view of head capsule; 7, dorsal view of prothoracic plate. A, anterior seta; Aa, anterior pore; $\mathrm{AF}$, adfrontal seta; $\mathrm{AFa}$, adfrontal pore; $\mathrm{C}$, clypeal seta; $\mathrm{D}$, dorsal seta; F, frontal seta; Fa, frontal pore; $\mathrm{L}$, lateral seta; $\mathrm{P}$, postero-dorsal seta; $\mathrm{Pa}$ and $\mathrm{Pb}$, postero-dorsal pores; S, stemmatal seta; Sb, stemmatal pore; SS, substemmatal seta; XD, prothoracic seta; XDc, prothoracic pore. Bars $=210 \mu \mathrm{m}$.

protuberances, but differs from those of $D$. juno juno and A. vanillae maculosa, in which protuberances are present (Kaminski et al. 2002; Tavares et al. 2002; Silva et al. 2006). The antennae (Fig. 12) are formed by three antennomeres: the first (An1) is short and wide; the second (An2) has four sensilla, one long and three short; and the third (An3) is reduced and has four short sensilla. Six stemmata (Fig. 11) are present, arranged in a semicircle.

The primary larval chaetotaxy (Fig. 6) is similar to that described for other heliconian larvae (Table I). The setae are smooth, of a chalaza type, and have a widened apex (Fig. 14). The presence of dilations on the apex of the primary setae was also observed for the first larval instar of other Heliconiini (Kaminski et al. 2002, 2008; Paim et al. 2004; Silva et al 2006, 2008). In the head capsule (Figs. 6, 10), pairs of setae, microsetae, and pores are clustered in ten groups (Table I). Other, smaller setae are also present on the labrum, maxillae, and mandibles (Stehr 1987). Chaetotaxy of the thorax and abdomen (Fig. 7-8) also with ten types of setal groups (Table I). The ventral group (V), when present, is represented by short thin setae (Fleming 1960). Pores and microsetae are found scattered over the larval body (Kitching 1984), but were omitted from this description.

The prothoracic plate (Fig. 7) has setae D1, D2, and XD2 and the pore XDc. Seta D2 is inserted more dorsally than XD2, differing from the description given by Fleming (1960) for $P$. dido, where it has a more dorsal position. Prothorax (T1) with SD1 larger than SD2; both inserted on the same pinaculum. Setae L1 and L2 of approximate size, located anterior to the spiracle and clustered on the same pinaculum. Setae SV1 and SV2 are also inserted on the same pinaculum, ventrally to the spiracle, with SV1 located in a posterior position to SV2. The meso- (T2) and metathorax (T3) have dorsal setae D1 and D2 on different pinacula, with D1 larger than D2 and located in a dorsal position. Subdorsal group represented by setae SD1 and SD2, both on the same pinaculum, but with SD1 larger and located antero-dorsally. Lateral group composed by setae L1, as long as SD1. Subventral group represented by setae SV1, similar to other heliconians (see Antunes et al. 2002; Kaminski et al. 2002; Paim et al. 2004; Silva et al. 2006, 2008 ), but differing from $D$. juno juno and $D$. moneta moneta Hübner, 1825, where there is also the setae SV2 (Tavares et al. 2002; Kaminski et al. 2008). Legs with tarsal and tibial setae, with the latter represented by Ts1, Ts2, Ts3, Ts4 (sensu Miller 1991), and Ts4 long and curved, similar to a claw (Fig. 16).

On the first and second abdominal segments (AB), the dorsal group is represented by the setae D1 and D2 on different pinacula, with D2 smaller than on the pinacula of $\mathrm{T} 2$ and T3, and located dorsally in relation to them. Subdorsal group formed by the setae SD1. Setae L1 and L2 on different pinacula, ventral to the spiracle; L2 located anteroventrally to L1. Subventral group composed by short, thin setae; SV1 present on both segments, and SV2 only on the second one.

From $\mathrm{AB} 3$ to $\mathrm{AB} 8$, the dorsal, subdorsal, and lateral setae are similar to those on the anterior segments. Subventral setae SV1 and SV2 inserted on the cylindrical sections of prolegs from AB3 to AB6; only SV1 present on the seventh and eighth segments in this case.

On the ninth $\mathrm{AB}$, setae D1 and D2 are located dorsally, with $\mathrm{D} 2$ longer than those found on the anterior AB. Subdorsal group composed only by setae SD1, located more ventrally in relation to the anterior segments. Lateral group represented by setae L1, and subventral group by SV1. On the tenth AB, setae of the dorsal and subdorsal groups clustered on the anal plate. Dorsal composed by D1 and D2, with D1 longer; SD1 and SD2 are present in the subdorsal group. Setae of the paraproctal group PP1 (sensu Stehr 1987), and subparaproctal group SP1 (sensu Kitching 1984), shorter and thinner in comparison to the others; SP1 more ventrally located. The anal proleg has setae PL1, PL2, PL3, PL4, and PL5, the latter visible only in ventral view. The chaetotaxy of this segment is similar to that described for other Heliconiini (Antunes et al. 2002; Kaminski et al. 2002, 2008; Tavares et al. 2002; Paim et al. 2004; Silva et al. 2006, 2008).

Tegument with conical microtrichia on the ventral region 
Table I. Distribution of setae on the first instar of heliconian butterflies. Pw, Philaethria wernickei; Pd, Philaethria dido; Avm, Agraulis vanillae maculosa; Djj, Dione juno juno; Dmm, Dione moneta moneta; Dp, Dryadula phaetusa; Dia, Dryas iulia alcionea; Eid, Eueides isabella dianasa; Hep, Heliconius erato phyllis. A, anterior seta; $\mathrm{AB}$, abdominal segment; $\mathrm{AF}$, adfrontal seta; C, clypeal seta; $\mathrm{CD}$, cephalodorsal seta; D, dorsal seta; F, frontal seta; $\mathrm{H}$, head; $\mathrm{L}$, lateral seta; $\mathrm{MG}$, microgenal seta; $\mathrm{P}$, posterior-dorsal seta; PL, seta of the anal proleg; PP, paraproctal seta; S, stemmatal seta; SD, subdorsal seta; SP, subparaproctal seta; SS, substemmatal seta; SV, subventral seta; $\mathrm{T}$, thoracic segment; $\mathrm{V}$, ventral seta; $\mathrm{XD}$, prothoracic seta. aPresent study; ${ }^{\mathrm{b}}$ Fleming (1960); ' ${ }^{\mathrm{a}} \mathrm{Silva}$ et al. (2006); ${ }^{\mathrm{d}}$ Tavares et al. (2002); ${ }^{\mathrm{e}} \mathrm{Kaminski}$ et al. (2008); 'Silva et al. (2008); 'Paim et al. (2004); ${ }^{\mathrm{h}} \mathrm{Antunes}$ et al. (2002); 'Kaminski et al. (2002). (-) absent; (x) present; (?) without mention in the reference; $(*)$ additional observation.

\begin{tabular}{|c|c|c|c|c|c|c|c|c|c|c|}
\hline \multirow[b]{2}{*}{ Body part } & \multirow[b]{2}{*}{ Seta } & \multicolumn{9}{|c|}{ Species } \\
\hline & & $\mathrm{Pw}^{\mathrm{a}}$ & $\mathrm{Pd}^{\mathrm{b}}$ & $\operatorname{Avm}^{c}$ & $\mathrm{Djj}^{\mathrm{d}}$ & $\mathrm{Dmm}^{\mathrm{e}}$ & $\mathrm{Dp}^{\mathrm{f}}$ & $\mathrm{Dia}^{\mathrm{g}}$ & Eid $^{\mathrm{h}}$ & Hep \\
\hline \multirow[t]{21}{*}{$\mathrm{H}$} & A1 & $\mathrm{x}$ & $\mathrm{x}$ & $\mathrm{x}$ & $\mathrm{x}$ & $\mathrm{x}$ & $\mathrm{x}$ & $\mathrm{x}$ & $\mathrm{x}$ & $\mathrm{x}$ \\
\hline & A2 & $\mathrm{x}$ & $\mathrm{x}$ & $\mathrm{x}$ & $\mathrm{x}$ & $\mathrm{x}$ & $\mathrm{x}$ & $\mathrm{x}$ & $\mathrm{x}$ & $\mathrm{x}$ \\
\hline & A3 & $\mathrm{x}$ & $\mathrm{x}$ & $\mathrm{x}$ & $\mathrm{x}$ & $\mathrm{x}$ & $\mathrm{x}$ & $\mathrm{x}$ & $x$ & $\mathrm{x}$ \\
\hline & AF1 & $\mathrm{x}$ & $\mathrm{x}$ & $\mathrm{x}$ & $\mathrm{x}$ & $\mathrm{x}$ & $\mathrm{x}$ & $\mathrm{x}$ & $\mathrm{x}$ & $\mathrm{x}$ \\
\hline & AF2 & $\mathrm{x}$ & $\mathrm{x}$ & $\mathrm{x}$ & $\mathrm{x}$ & $\mathrm{x}$ & $\mathrm{x}$ & $\mathrm{x}$ & $\mathrm{x}$ & $\mathrm{x}$ \\
\hline & $\mathrm{C} 1$ & $\mathrm{x}$ & $\mathrm{x}$ & $\mathrm{x}$ & $\mathrm{x}$ & $\mathrm{x}$ & $\mathrm{x}$ & $\mathrm{x}$ & $\mathrm{x}$ & $\mathrm{x}$ \\
\hline & $\mathrm{C} 2$ & $\mathrm{x}$ & $\mathrm{x}$ & $\mathrm{x}$ & $\mathrm{x}$ & $\mathrm{x}$ & $\mathrm{x}$ & $\mathrm{x}$ & $\mathrm{x}$ & $\mathrm{x}$ \\
\hline & CD1 & $\mathrm{x}$ & ? & $\mathrm{x}$ & $\mathrm{x}$ & $\mathrm{x}$ & $\mathrm{x}$ & $\mathrm{x}$ & ? & $\mathrm{x}$ \\
\hline & $\mathrm{CD} 2$ & $\mathrm{x}$ & $?$ & $\mathrm{x}$ & $\mathrm{x}$ & $\mathrm{x}$ & $\mathrm{x}$ & $\mathrm{x}$ & $?$ & $\mathrm{x}$ \\
\hline & CD3 & $\mathrm{x}$ & $?$ & $\mathrm{x}$ & $\mathrm{x}$ & $\mathrm{x}$ & $\mathrm{x}$ & $\mathrm{x}$ & $?$ & $\mathrm{x}$ \\
\hline & F1 & $\mathrm{x}$ & $\mathrm{x}$ & $\mathrm{x}$ & $\mathrm{x}$ & $\mathrm{x}$ & $\mathrm{x}$ & $\mathrm{x}$ & $\mathrm{x}$ & $\mathrm{x}$ \\
\hline & L1 & $\mathrm{x}$ & $\mathrm{x}$ & $\mathrm{x}$ & $\mathrm{x}$ & $\mathrm{x}$ & $\mathrm{x}$ & $\mathrm{x}$ & $\mathrm{x}$ & $\mathrm{x}$ \\
\hline & MG1 & $\mathrm{x}$ & $?$ & $?$ & $?$ & $\mathrm{x}$ & $\mathrm{x}$ & $?$ & $?$ & $?$ \\
\hline & P1 & $\mathrm{x}$ & $\mathrm{x}$ & $\mathrm{x}$ & $\mathrm{x}$ & $\mathrm{x}$ & $\mathrm{x}$ & $\mathrm{x}$ & $\mathrm{x}$ & $\mathrm{x}$ \\
\hline & P2 & $\mathrm{x}$ & $\mathrm{x}$ & $\mathrm{x}$ & $x$ & $\mathrm{x}$ & $\mathrm{x}$ & $\mathrm{x}$ & $\mathrm{x}$ & $\mathrm{x}$ \\
\hline & $\mathrm{S} 1$ & $\mathrm{x}$ & $\mathrm{x}$ & $\mathrm{x}$ & $\mathrm{x}$ & $\mathrm{x}$ & $\mathrm{x}$ & $\mathrm{x}$ & $\mathrm{x}$ & $\mathrm{x}$ \\
\hline & S2 & $\mathrm{x}$ & $\mathrm{x}$ & $\mathrm{x}$ & $\mathrm{x}$ & $\mathrm{x}$ & $\mathrm{x}$ & $\mathrm{x}$ & $\mathrm{x}$ & $\mathrm{x}$ \\
\hline & S3 & $\mathrm{x}$ & $\mathrm{x}$ & $\mathrm{x}$ & $\mathrm{x}$ & $\mathrm{x}$ & $\mathrm{x}$ & $\mathrm{x}$ & $\mathrm{x}$ & $\mathrm{x}$ \\
\hline & SS1 & $\mathrm{x}$ & $\mathrm{x}$ & $\mathrm{x}$ & $\mathrm{x}$ & $\mathrm{x}$ & $\mathrm{x}$ & $\mathrm{x}$ & $\mathrm{x}$ & $\mathrm{x}$ \\
\hline & SS2 & $\mathrm{x}$ & $\mathrm{x}$ & $\mathrm{x}$ & $\mathrm{x}$ & $\mathrm{x}$ & $x$ & $\mathrm{x}$ & $\mathrm{x}$ & $\mathrm{x}$ \\
\hline & SS3 & $\mathrm{x}$ & $\mathrm{x}$ & $\mathrm{x}$ & $\mathrm{x}$ & $\mathrm{x}$ & $\mathrm{x}$ & $\mathrm{x}$ & $\mathrm{x}$ & $\mathrm{x}$ \\
\hline \multirow[t]{9}{*}{$\mathrm{T} 1$} & $\mathrm{XD} 2$ & $\mathrm{x}$ & $\mathrm{x}$ & $\mathrm{x}$ & $\mathrm{x}$ & $\mathrm{x}$ & $\mathrm{x}$ & $\mathrm{x}$ & $\mathrm{x}$ & $\mathrm{x}$ \\
\hline & D1 & $\mathrm{x}$ & $\mathrm{x}$ & $\mathrm{x}$ & $x$ & $\mathrm{x}$ & $\mathrm{x}$ & $\mathrm{x}$ & $\mathrm{x}$ & $\mathrm{x}$ \\
\hline & D2 & $\mathrm{x}$ & $\mathrm{x}$ & $\mathrm{x}$ & $\mathrm{x}$ & $\mathrm{x}$ & $\mathrm{x}$ & $\mathrm{x}$ & $\mathrm{x}$ & $\mathrm{x}$ \\
\hline & SD1 & $\mathrm{x}$ & $\mathrm{x}$ & $\mathrm{x}$ & $\mathrm{x}$ & $\mathrm{x}$ & $\mathrm{x}$ & $\mathrm{x}$ & $\mathrm{x}$ & $\mathrm{x}$ \\
\hline & SD2 & $\mathrm{x}$ & $\mathrm{x}$ & $\mathrm{x}$ & $\mathrm{x}$ & $\mathrm{x}$ & $\mathrm{x}$ & $\mathrm{x}$ & $\mathrm{x}$ & $\mathrm{x}$ \\
\hline & L1 & $\mathrm{x}$ & $\mathrm{x}$ & $\mathrm{x}$ & $x$ & $\mathrm{x}$ & $\mathrm{x}$ & $\mathrm{x}$ & $\mathrm{x}$ & $\mathrm{x}$ \\
\hline & L2 & $\mathrm{x}$ & $\mathrm{x}$ & $\mathrm{x}$ & $\mathrm{x}$ & $\mathrm{x}$ & $x$ & $\mathrm{x}$ & $\mathrm{x}$ & $\mathrm{x}$ \\
\hline & SV1 & $\mathrm{x}$ & $\mathrm{x}$ & $\mathrm{x}$ & $\mathrm{x}$ & $\mathrm{x}$ & $\mathrm{x}$ & $\mathrm{x}$ & $\mathrm{x}$ & $\mathrm{x}$ \\
\hline & SV2 & $\mathrm{x}$ & $\mathrm{x}$ & $\mathrm{x}$ & $\mathrm{x}$ & $\mathrm{x}$ & $\mathrm{x}$ & $\mathrm{x}$ & $\mathrm{x}$ & $\mathrm{x}$ \\
\hline \multirow[t]{7}{*}{$\mathrm{T} 2-3$} & D1 & $\mathrm{x}$ & $\mathrm{x}$ & $\mathrm{x}$ & $\mathrm{x}$ & $\mathrm{x}$ & $\mathrm{x}$ & $\mathrm{x}$ & $\mathrm{x}$ & $\mathrm{x}$ \\
\hline & D2 & $x$ & $\mathrm{x}$ & $\mathrm{x}$ & $\mathrm{x}$ & $\mathrm{x}$ & $\mathrm{x}$ & $\mathrm{x}$ & $\mathrm{x}$ & $\mathrm{x}$ \\
\hline & SD1 & $\mathrm{x}$ & $\mathrm{x}$ & $\mathrm{x}$ & $\mathrm{x}$ & $\mathrm{x}$ & $\mathrm{x}$ & $\mathrm{x}$ & $\mathrm{x}$ & $\mathrm{x}$ \\
\hline & SD2 & $\mathrm{x}$ & $\mathrm{x}$ & $x^{*}$ & $\mathrm{x}$ & $\mathrm{x}$ & $\mathrm{x}$ & $\mathrm{x}$ & $\mathrm{x}$ & $\mathrm{x}$ \\
\hline & L1 & $\mathrm{x}$ & $\mathrm{x}$ & $\mathrm{x}$ & $\mathrm{x}$ & $\mathrm{x}$ & $\mathrm{x}$ & $\mathrm{x}$ & $\mathrm{x}$ & $\mathrm{x}$ \\
\hline & SV1 & $\mathrm{x}$ & $\mathrm{x}$ & $\mathrm{x}$ & $\mathrm{x}$ & $\mathrm{x}$ & $\mathrm{x}$ & $\mathrm{x}$ & $\mathrm{x}$ & $\mathrm{x}$ \\
\hline & SV2 & - & - & - & $\mathrm{x}$ & $\mathrm{x}$ & - & - & - & - \\
\hline \multirow[t]{8}{*}{$\mathrm{AB} 1$} & D1 & $\mathrm{x}$ & $\mathrm{x}$ & $\mathrm{x}$ & $\mathrm{x}$ & $\mathrm{x}$ & $\mathrm{x}$ & $\mathrm{x}$ & $\mathrm{x}$ & $\mathrm{x}$ \\
\hline & D2 & $\mathrm{x}$ & $\mathrm{x}$ & $\mathrm{x}$ & $\mathrm{x}$ & $\mathrm{x}$ & $x$ & $\mathrm{x}$ & $\mathrm{x}$ & $\mathrm{x}$ \\
\hline & SD1 & $\mathrm{x}$ & $\mathrm{x}$ & $\mathrm{x}$ & $\mathrm{x}$ & $\mathrm{x}$ & $\mathrm{x}$ & $\mathrm{x}$ & $\mathrm{x}$ & $\mathrm{x}$ \\
\hline & L1 & $\mathrm{x}$ & $\mathrm{x}$ & $\mathrm{x}$ & $\mathrm{x}$ & $\mathrm{x}$ & $\mathrm{x}$ & $\mathrm{x}$ & $\mathrm{x}$ & $\mathrm{x}$ \\
\hline & L2 & $\mathrm{x}$ & $\mathrm{x}$ & $\mathrm{x}$ & $\mathrm{x}$ & $x$ & $\mathrm{x}$ & $\mathrm{x}$ & $\mathrm{x}$ & $\mathrm{x}$ \\
\hline & SV1 & $\mathrm{x}$ & $\mathrm{x}$ & $\mathrm{x}$ & $\mathrm{x}$ & $\mathrm{x}$ & $\mathrm{x}$ & $\mathrm{x}$ & $\mathrm{x}$ & $\mathrm{x}$ \\
\hline & SV2 & - & - & $-*$ & - & - & - & - & - & - \\
\hline & V1 & $\mathrm{x}$ & $?$ & $\mathrm{x}^{*}$ & $\mathrm{x}^{*}$ & $\mathrm{x}^{*}$ & $\mathrm{x}^{*}$ & $\mathrm{x}$ & $x^{*}$ & $\mathrm{x}$ \\
\hline \multirow[t]{4}{*}{ AB2-6 } & D1 & $\mathrm{x}$ & $\mathrm{x}$ & $\mathrm{x}$ & $\mathrm{x}$ & $\mathrm{x}$ & $\mathrm{x}$ & $\mathrm{x}$ & $\mathrm{x}$ & $\mathrm{x}$ \\
\hline & D2 & $\mathrm{x}$ & $\mathrm{x}$ & $\mathrm{x}$ & $\mathrm{x}$ & $\mathrm{x}$ & $\mathrm{x}$ & $\mathrm{x}$ & $\mathrm{x}$ & $\mathrm{x}$ \\
\hline & SD1 & $\mathrm{x}$ & $\mathrm{x}$ & $\mathrm{x}$ & $\mathrm{x}$ & $\mathrm{x}$ & $\mathrm{x}$ & $\mathrm{x}$ & $\mathrm{x}$ & $\mathrm{x}$ \\
\hline & L1 & $\mathrm{x}$ & $\mathrm{x}$ & $\mathrm{x}$ & $\mathrm{x}$ & $\mathrm{x}$ & $\mathrm{x}$ & $\mathrm{x}$ & $\mathrm{x}$ & $\mathrm{x}$ \\
\hline
\end{tabular}

Table I. Cont.

\begin{tabular}{|c|c|c|c|c|c|c|c|c|c|c|}
\hline \multirow[b]{2}{*}{ Body part } & \multirow[b]{2}{*}{ Seta } & \multicolumn{9}{|c|}{ Species } \\
\hline & & $\mathrm{Pw}^{\mathrm{a}}$ & $\mathrm{Pd}^{\mathrm{b}}$ & $\operatorname{Avm}^{c}$ & $\mathrm{Djj}^{\mathrm{d}}$ & $\mathrm{Dmm}^{\mathrm{e}}$ & $D p^{f}$ & $\mathrm{Dia}^{\mathrm{g}}$ & Eid $^{\mathrm{h}}$ & Hep \\
\hline \multirow{10}{*}{ AB7-8 } & L2 & $\mathrm{x}$ & $\mathrm{x}$ & $\mathrm{x}$ & $\mathrm{x}$ & $\mathrm{x}$ & $\mathrm{x}$ & $\mathrm{x}$ & $\mathrm{x}$ & $\mathrm{x}$ \\
\hline & SV1 & $\mathrm{x}$ & $\mathrm{x}$ & $\mathrm{x}$ & $\mathrm{x}$ & $\mathrm{x}$ & $\mathrm{x}$ & $\mathrm{x}$ & $\mathrm{x}$ & $\mathrm{x}$ \\
\hline & SV2 & $\mathrm{x}$ & $\mathrm{x}$ & $\mathrm{x}$ & $\mathrm{x}^{*}$ & $\mathrm{x}$ & $\mathrm{x}$ & $\mathrm{x}^{*}$ & $\mathrm{x}$ & $\mathrm{x}$ \\
\hline & V1 & $\mathrm{x}$ & $?$ & $\mathrm{x}^{*}$ & $\mathrm{x}^{*}$ & $x^{*}$ & $\mathrm{x}^{*}$ & $\mathrm{x}$ & $x^{*}$ & $\mathrm{x}$ \\
\hline & D1 & $\mathrm{x}$ & $\mathrm{x}$ & $\mathrm{x}$ & $\mathrm{x}$ & $\mathrm{x}$ & $\mathrm{x}$ & $\mathrm{x}$ & $\mathrm{x}$ & $\mathrm{x}$ \\
\hline & D2 & $\mathrm{x}$ & $\mathrm{x}$ & $\mathrm{x}$ & $\mathrm{x}$ & $\mathrm{x}$ & $\mathrm{x}$ & $\mathrm{x}$ & $\mathrm{x}$ & $\mathrm{x}$ \\
\hline & SD1 & $\mathrm{x}$ & $\mathrm{x}$ & $\mathrm{x}$ & $\mathrm{x}$ & $\mathrm{x}$ & $\mathrm{x}$ & $\mathrm{x}$ & $\mathrm{x}$ & $\mathrm{x}$ \\
\hline & L1 & $\mathrm{x}$ & $\mathrm{x}$ & $\mathrm{x}$ & $\mathrm{x}$ & $\mathrm{x}$ & $\mathrm{x}$ & $\mathrm{x}$ & $\mathrm{x}$ & $\mathrm{x}$ \\
\hline & L2 & $\mathrm{x}$ & $\mathrm{x}$ & $\mathrm{x}$ & $\mathrm{x}$ & $\mathrm{x}$ & $\mathrm{x}$ & $\mathrm{x}$ & $\mathrm{x}$ & $\mathrm{x}$ \\
\hline & SV1 & $\mathrm{x}$ & $\mathrm{x}$ & $\mathrm{x}$ & $\mathrm{x}$ & $\mathrm{x}$ & $\mathrm{x}$ & $\mathrm{x}$ & $\mathrm{x}$ & $\mathrm{x}$ \\
\hline \multirow{4}{*}{ AB9 } & V1 & - & $?$ & $-*$ & $-*$ & $-*$ & -* & $-*$ & $-*$ & -* \\
\hline & D1 & $\mathrm{x}$ & $\mathrm{x}$ & $\mathrm{x}$ & $\mathrm{x}$ & $\mathrm{x}$ & $\mathrm{x}$ & $\mathrm{x}$ & $\mathrm{x}$ & $\mathrm{x}$ \\
\hline & D2 & $\mathrm{x}$ & $\mathrm{x}$ & $\mathrm{x}$ & $\mathrm{x}$ & $\mathrm{x}$ & $\mathrm{x}$ & $\mathrm{x}$ & $\mathrm{x}$ & $\mathrm{x}$ \\
\hline & SD1 & $\mathrm{x}$ & $\mathrm{x}$ & $\mathrm{x}$ & $\mathrm{x}$ & $\mathrm{x}$ & $\mathrm{x}$ & $\mathrm{x}$ & $\mathrm{x}$ & $\mathrm{x}$ \\
\hline \multirow{14}{*}{ AB10 } & L1 & $\mathrm{x}$ & $\mathrm{x}$ & $\mathrm{x}$ & $\mathrm{x}$ & $\mathrm{x}$ & $\mathrm{x}$ & $\mathrm{x}$ & $\mathrm{x}$ & $\mathrm{x}$ \\
\hline & SV1 & $\mathrm{x}$ & $\mathrm{x}$ & $\mathrm{x}$ & $\mathrm{x}$ & $\mathrm{x}$ & $\mathrm{x}$ & $\mathrm{x}$ & $\mathrm{x}$ & $\mathrm{x}$ \\
\hline & SV2 & - & - & - & - & $-*$ & - & - & - & - \\
\hline & D1 & $\mathrm{x}$ & $?$ & $\mathrm{x}$ & $\mathrm{x}$ & $\mathrm{x}$ & $\mathrm{x}$ & $\mathrm{x}$ & $\mathrm{x}$ & $\mathrm{x}$ \\
\hline & D2 & $\mathrm{x}$ & $?$ & $\mathrm{x}$ & $\mathrm{x}$ & $\mathrm{x}$ & $\mathrm{x}$ & $\mathrm{x}$ & $\mathrm{x}$ & $\mathrm{x}$ \\
\hline & SD1 & $\mathrm{x}$ & $?$ & $\mathrm{x}$ & $\mathrm{x}$ & $\mathrm{x}$ & $\mathrm{x}$ & $\mathrm{x}$ & $\mathrm{x}$ & $\mathrm{x}$ \\
\hline & SD2 & $\mathrm{x}$ & $?$ & $\mathrm{x}$ & $\mathrm{x}$ & $\mathrm{x}$ & $\mathrm{x}$ & $\mathrm{x}$ & $x^{*}$ & $\mathrm{x}$ \\
\hline & PP1 & $\mathrm{x}$ & $?$ & $\mathrm{x}$ & $\mathrm{x}^{*}$ & $\mathrm{x}$ & $\mathrm{x}$ & $\mathrm{x}$ & $\mathrm{x}$ & $\mathrm{x}$ \\
\hline & SP1 & $\mathrm{x}$ & $?$ & $\mathrm{x}$ & $\mathrm{x}^{*}$ & $\mathrm{x}$ & $\mathrm{x}$ & $\mathrm{x}$ & $\mathrm{x}^{*}$ & $\mathrm{x}$ \\
\hline & PL1 & $\mathrm{x}$ & $?$ & $\mathrm{x}$ & $\mathrm{x}$ & $\mathrm{x}$ & $\mathrm{x}$ & $\mathrm{x}$ & $\mathrm{x}^{*}$ & $\mathrm{x}$ \\
\hline & PL2 & $\mathrm{x}$ & $?$ & $\mathrm{x}$ & $\mathrm{x}$ & $\mathrm{x}$ & $\mathrm{x}$ & $\mathrm{x}$ & $\mathrm{x}^{*}$ & $\mathrm{x}$ \\
\hline & PL3 & $\mathrm{x}$ & $?$ & $\mathrm{x}$ & $\mathrm{x}$ & $\mathrm{x}$ & $\mathrm{x}$ & $\mathrm{x}$ & $x^{*}$ & $\mathrm{x}$ \\
\hline & PL4 & $\mathrm{x}$ & $?$ & $\mathrm{x}$ & $\mathrm{x}$ & $\mathrm{x}$ & $\mathrm{x}$ & $\mathrm{x}$ & $\mathrm{x}^{*}$ & $\mathrm{x}$ \\
\hline & PL5 & $\mathrm{x}$ & $?$ & $\mathrm{x}^{*}$ & $\mathrm{x}^{*}$ & $\mathrm{x}$ & $\mathrm{x}$ & $\mathrm{x}^{*}$ & $\mathrm{x}^{*}$ & $\mathrm{x}^{*}$ \\
\hline
\end{tabular}

(Fig. 18) and close to the bases of the legs and prolegs (Figs. 16-17). Spiracles and prolegs follow the general pattern described for Lepidoptera (Stehr 1987). Spiracles are round and have an elevated peritreme (Fig. 15), and are present on $\mathrm{T} 1$ and from $\mathrm{AB} 1$ to $\mathrm{AB} 8$, with the first and last larger than the others. On the bases of the prolegs, uniordinal and uniserial crochets are organised circularly (Fig. 17).

The chaetotaxy changes after the second instar: primary setae are replaced by secondary setae, scoli, and verrucae. The head capsule bears a pair of long, backwards-curved, cephalic scoli (Sc). The position of the scoli is similar to that of the primary setae in the first instar. Their distribution pattern remains constant in the subsequent instars, similar to the observations for other Heliconiini (Table II). The scoli are long thick structures that bear several setae (Fig. 19); they are located on pinacula and have a fine apex, a common characteristic among heliconians (Penz 1999). The distal region of dorsal scoli has micropores that communicate with an inner central channel (Figs. 20-21). Until now, this characteristic has not been recorded for heliconinans. The fifth larval instar of $P$. wernickei bears long scoli, especially the dorsal (So) scoli, which in lateral view exceed in length by up to 1.5 times the height of the body segment on which they are inserted (Fig. 9).

The tegument of the fifth instar is covered by microtrichia and scattered secondary setae. The microtrichia are conical and striated (Fig. 23), similar to the structure found in $D$. 

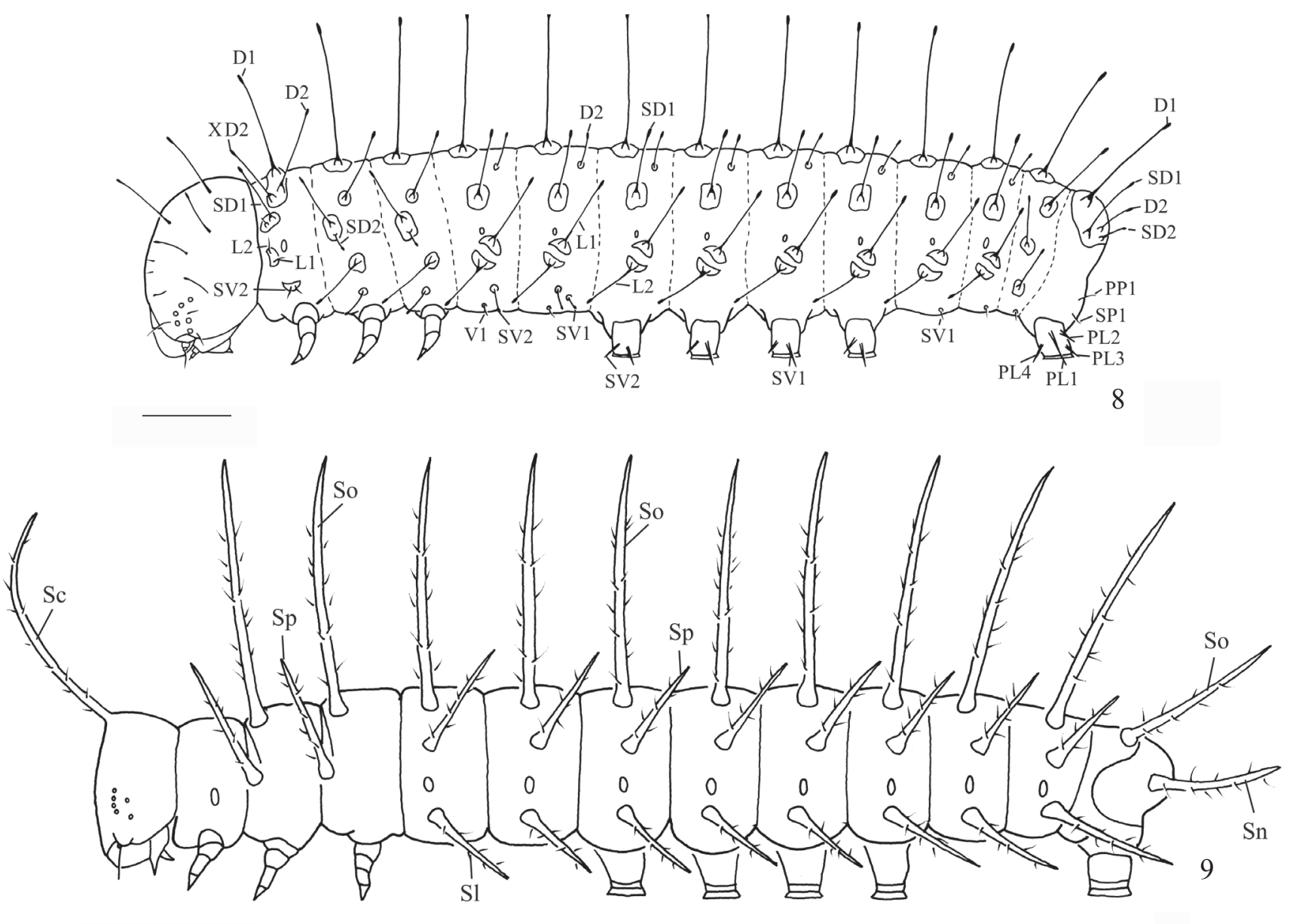

Figs. 8-9. Larva of Philaethria wernickei (Röber, 1906) in lateral view. 8, first instar; 9, fifth instar. D, dorsal seta; L, lateral seta; PL, seta of proleg cylindrical section of tenth abdominal segment; PP, paraproctal seta; Sc, cephalic scolus; SD, subdorsal seta; Sl, subspiracular scolus; Sn, anal scolus; So, dorsal scolus; SP, subparaproctal seta; Sp, supraspiracular scolus; SV, subventral seta; V, ventral seta; XD, prothoracic seta. Bars $=0.54$ and $1.5 \mathrm{~mm}$, respectively.

iulia alcionea (Cramer, 1779) (Paim et al. 2004), D. moneta moneta (Kaminski et al. 2008), and D. phaetusa (Silva et al. 2008). The spiracles are elliptical, with a slightly elevated peritreme (Fig. 24) compared to the first instar. Crochets of prolegs are uniserial and triordinal (Fig. 22).

\section{Instar identification}

We found no stable differences, either in shape or colouration, among the instars of $P$. wernickei that would allow their accurate identification. However, identification was achieved through measurements of the head capsules, because there was no overlap between corresponding values among instars (Tab. III). For the five instars the following exponential growth equation was adjusted: $\mathrm{y}=0.501$ $\mathrm{e}^{\wedge} 0.381 \mathrm{x} ; \mathrm{n}=53 ; \mathrm{r}=0.98 ; \mathrm{p}=0.0001$. The mean growth ratio among instars was 1.51 , similar to ratios previously observed for other heliconians (Antunes et al. 2002; Kaminski et al. 2002, 2008; Tavares et al. 2002; Paim et al. 2004; Silva et al. 2006, 2008).

Pupa (Figs. 27-44)

Colouration (Fig. 27) is not uniform, being composed of a mixture of shades of beige, grey, greenish-grey, and brown. Pairs of golden spots are present on the prothorax and metathorax, as well as on abdominal segments $\mathrm{AB} 1$ and $\mathrm{AB} 2$, with the spots on the metathorax and $\mathrm{AB} 1$ larger than the others.

With respect to the generic morphology, prothoracic (Le1) and mesothoracic (Le2) legs extend antero-ventrally (Fig. 28), touching the posterior margin of the ocular region; the epicranial suture is absent, similar to other Heliconiini, and thus follows the pattern proposed by Mosher (1916) for Nymphalidae.

The pupa has a pair of short cephalic projections (Figs. 30, 33), with a corrugated aspect. The ocular area (Fig. 31) has two distinct regions: a narrow band with a glazed surface (Gr), surrounding the central portion ( $\mathrm{Sr}$ ), which is corrugated and has setae (Fig. 35), similar to other heliconians (Antunes et al. 2002; Kaminski et al. 2002, 2008; Tavares et al. 2002; Paim et al. 2004; Silva et al. 2006, 2008). The mandibles (Md, Fig. 28) are located ventrally. Between them is a labrum (Lb, Fig. 28), and anterior to the labrum is a clypeus $(\mathrm{Cl}$, Fig. 28). Maxillae are located posteriorly to these structures (Mx, Fig. 28), expanding to the distal portion of the antennae. 

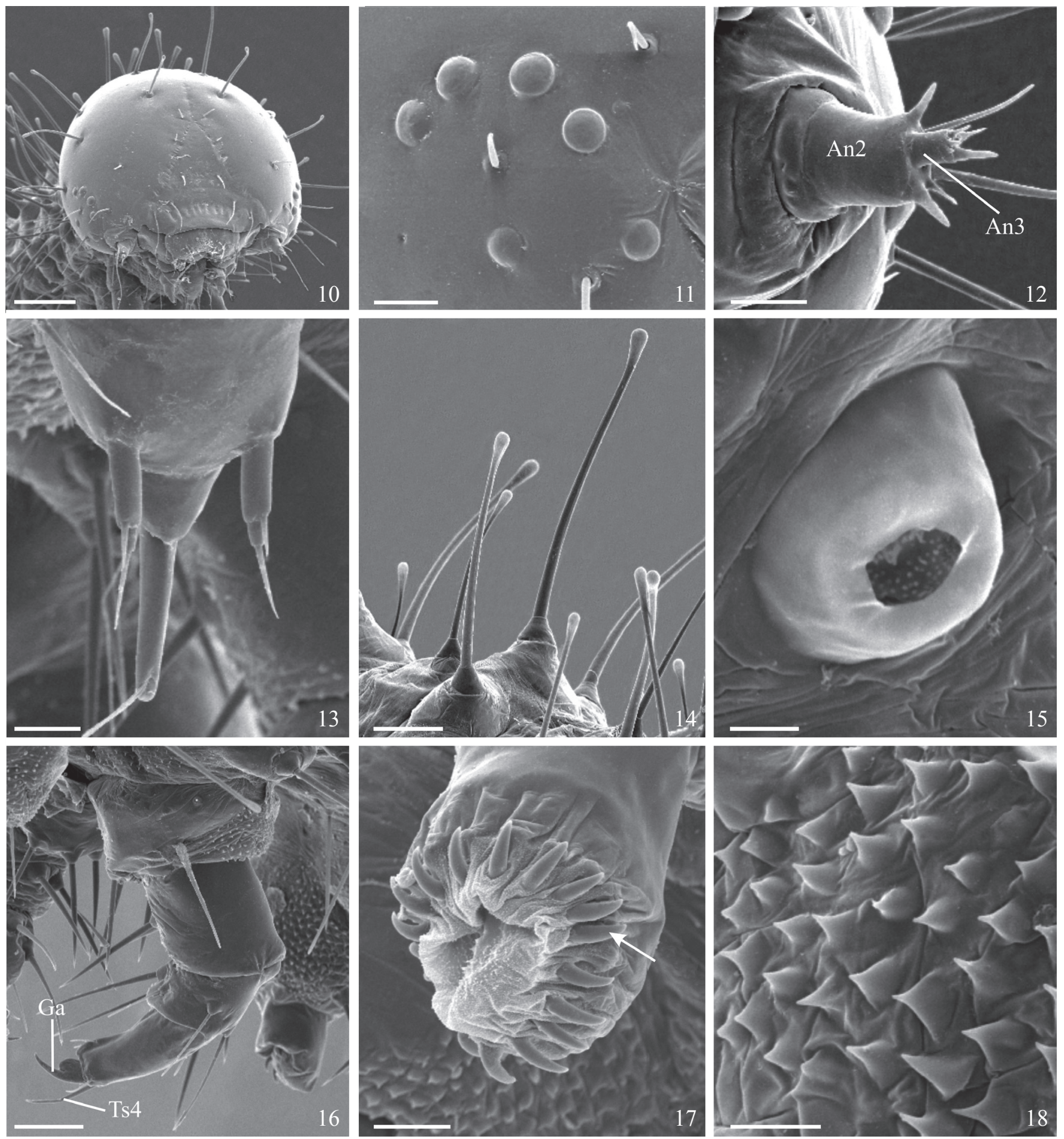

Figs. 10-18. Scanning electron micrographs of the first-instar larva of Philaethria wernickei (Röber, 1906). 10, latero-frontal view of head; 11, stemmatal region, lateral view; 12, antenna; 13, spinneret; 14, chalazae, lateral view; 15, spiracle of second abdominal segment; 16, metathoracic leg; 17, base of proleg with exposed crochets (arrow); 18, microtrichia. An, antennomere; Ga, tarsal claw; Ts, tarsal seta. Bars $=200,40,30,20,80,5$, 60, 20, and 10 $\mu \mathrm{m}$, respectively.

These originate dorsally on the head (Figs. 28-29), extending ventrally between the meso-thoracic legs and anterior wings. The antennomeres (Fig. 34) bear knob-shaped tubercles, similar in shape to but more pronounced than those found in A. vanillae maculosa (Silva et al. 2006).

The three thoracic segments are distinctive in shape and size (Fig. 30), following the pattern described by Beebe et al. (1960). The prothorax (T1) has a pair of latero-dorsal tubercles (Lt), similar to D. juno juno (Tavares et al. 2002). The mesothorax (T2), the largest thoracic segment, bears three pairs of tubercles in line with the latero-dorsal row of tubercles (Figs. 29-30), which have not been recorded for 

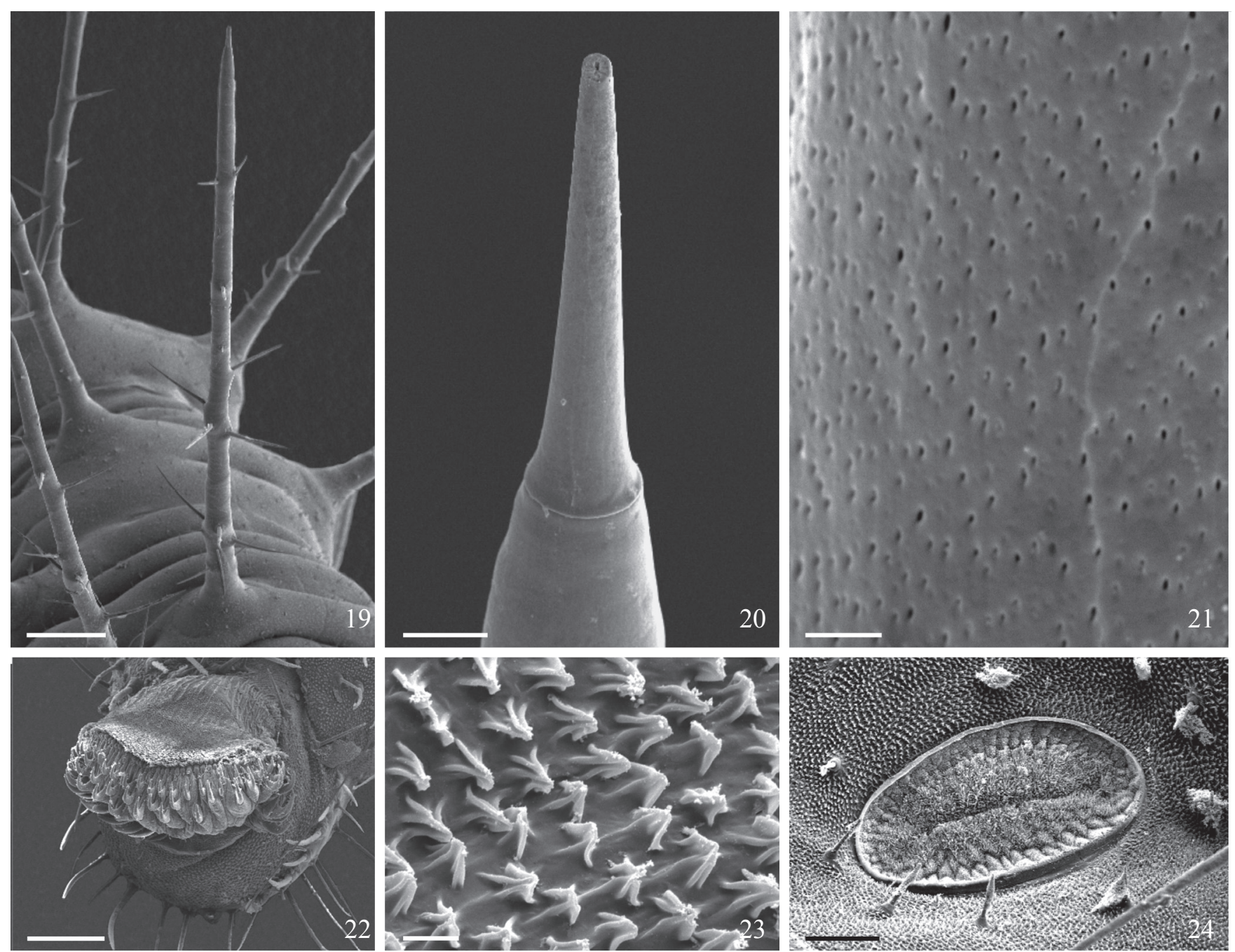

Figs. 19-24. Scanning electron micrographs of the fifth-instar larva of Philaethria wernickei (Röber, 1906). 19, dorsal scoli; 20, apex of scolus; 21, detail of scolus apex wall; 22, base of proleg with exposed crochets; 23, microtrichia; 24, spiracle of eighth abdominal segment. Bars =700, 40, 2, 300, 10, and 130 $\mu \mathrm{m}$, respectively.

other heliconinans. The mesothorax has a flat, pronounced, corrugated meso-dorsal crest with a median disk-shaped protuberance. Such a protuberance also has not been previously observed for Heliconiini. On the metathorax, there is a pair of latero-dorsal tubercles. At the base of each anterior wing (Fig. 29, 36) are a longitudinal crest (Bl) and a basilar tubercle (Bt). This tubercle has protuberances, like that of $D$. juno juno (Tavares et al. 2002), and differs from the smooth tubercle in A. vanillae maculosa (Silva et al. 2006) and $H$. erato phyllis (Kaminski et al. 2002). Near the distal margin of the anterior wing are three submarginal tubercles (St) (Fig. 28); there are also three postmedian tubercles (sensu Beebe et al., 1960) and an additional one within the discal cell. Prothoracic legs (Figs. 28, 32) are short and have a tubercle on the median portion. Mesothoracic legs (Figs. 28, 32) are located between the prothoracic legs and the antennae, and have a tubercle on the median portion. Metathoracic legs are completely covered by the anterior wings.

In dorsal view (Fig. 29), the abdomen has five rows of tubercles: one dorso-mesal (Mt), one pair of dorso-lateral
Table II. Distribution of scoli on the fifth instar of heliconian butterflies. Pw, Philaethria wernickei; Pd, Philaethria dido; Avm, Agraulis vanillae maculosa; Djj, Dione juno juno; Dmm, Dione moneta moneta; Dp, Dryadula phaetusa; Dia, Dryas iulia alcionea; Eid, Eueides isabella dianasa; Hep, Heliconius erato phyllis. AB, abdominal segment; $\mathrm{H}$, head; Sc, cephalic scolus; Sl, subspiracular scolus; Sn, anal scolus; So, dorsal scolus; Sp, supraspiracular scolus; St, prothoracic scolus; T, thoracic segment. ${ }^{a}$ Present study; ${ }^{b}$ Beebe et al. (1960); 'Silva et al. (2006); ${ }^{\mathrm{d}}$ Tavares et al. (2002); ${ }^{\mathrm{e}} \mathrm{Kaminski}$ et al. (2008); ${ }^{\mathrm{f} S i l v a}$ et al. (2008); ${ }^{\mathrm{g}} \mathrm{Paim}$ et al. (2004); ${ }^{\mathrm{h}}$ Antunes et al. (2002); 'Kaminski et al. (2002). (-) absent; (x) present.

\section{Species}

Body part Scolus $\mathrm{Pw}^{\mathrm{a}} \mathrm{Pd}^{\mathrm{b}} \mathrm{Avm}^{\mathrm{c}} \mathrm{Djj}^{\mathrm{d}} \mathrm{Dmm}^{\mathrm{e}} \mathrm{Dp}^{\mathrm{f}} \mathrm{Dia}^{\mathrm{g}}$ Eid $^{\mathrm{h}} \mathrm{Hep}^{\mathrm{i}}$

\begin{tabular}{ccccccccccc}
\hline H & Sc & x & x & x & x & x & x & x & x & x \\
T1 & St & - & - & - & x & - & - & - & - & - \\
T2-3 & So & x & x & x & x & x & x & x & x & x \\
& Sp & x & x & x & x & x & x & x & x & x \\
AB1-8 & So & x & x & x & x & x & x & x & x & x \\
& Sp & x & x & x & x & x & x & x & x & x \\
& S1 & x & x & x & x & x & x & x & x & x \\
AB9 & So & x & x & x & x & x & x & x & x & x \\
AB10 & Sn & x & x & x & x & x & x & x & x & x \\
\hline
\end{tabular}




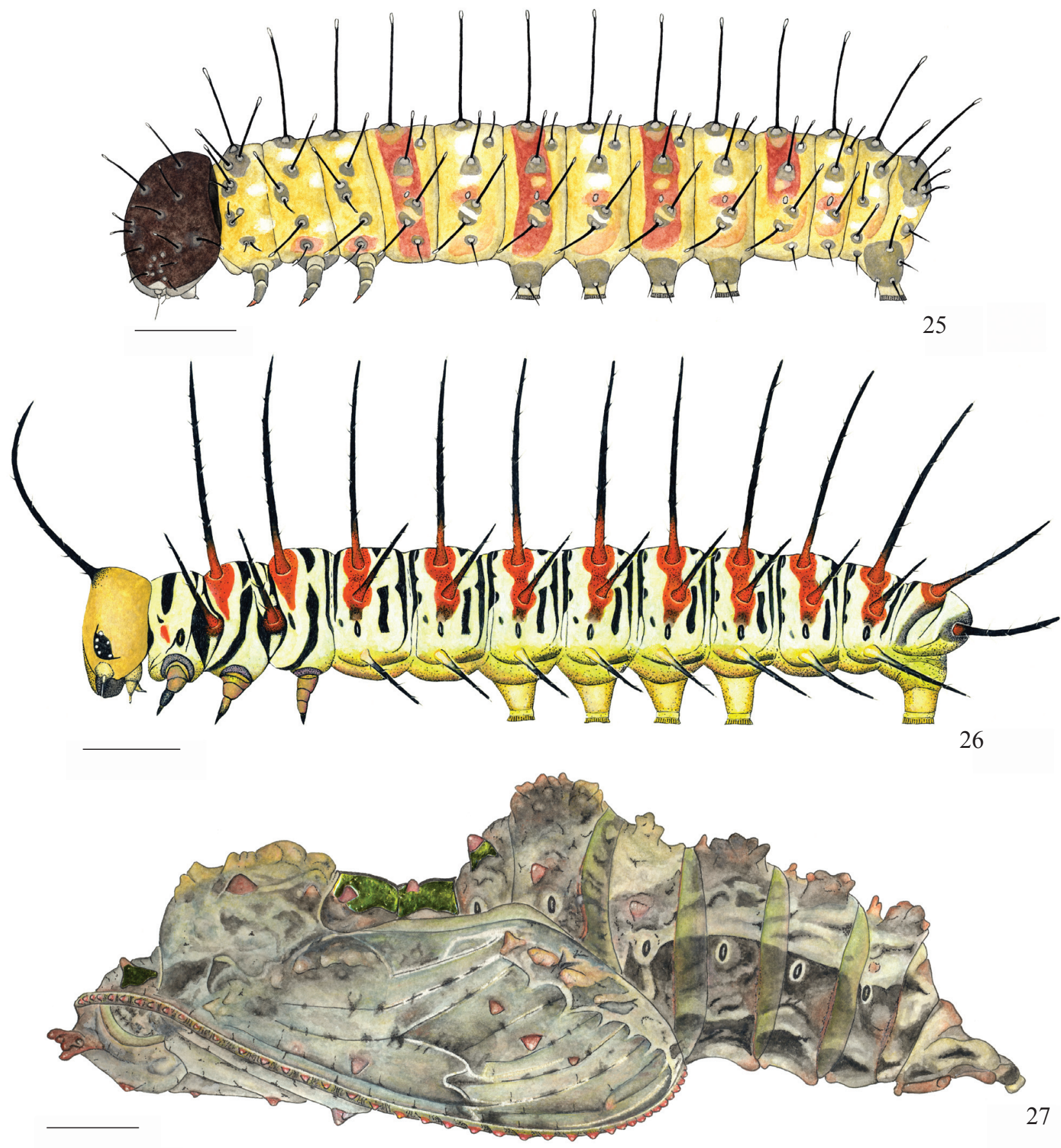

Figs. 25-27. Colouration pattern of Philaethria wernickei (Röber, 1906) larval and pupal stages. 25, newly hatched first-instar larva, lateral view; 25, freshly molted fifth-instar larva, lateral view; 26, pupa, lateral view. Bars $=0.5,2$, and $2 \mathrm{~mm}$, respectively.

(Lt), and a pair of supraspiracular (Se). The dorso-mesal row (Figs. 29, 38) is distributed from AB5 to AB7, differing from E. isabella dianasa, which has these structures from $\mathrm{AB} 3$ to AB6 (Antunes et al. 2002). The dorso-lateral tubercles (Figs. $29,37)$ are located from $\mathrm{AB} 1$ to $\mathrm{AB} 8$, being more apparent on $\mathrm{AB} 3$, similar to D. juno juno (Tavares et al. 2002). They differ from that in H. erato phyllis in lacking spines (Kaminski et al. 2002). The supra-spiracular tubercles, present on $\mathrm{AB} 3$ and $\mathrm{AB} 4$, are similar to those in D. iulia alcionea (Paim et al. 2004) and D. juno juno (Tavares et al. 2002).
The abdomen has two rows of subspiracular tubercles (Sb, Figs. 28, 39). A row of tubercles (Vt, Fig. 28) is visible in ventral view, from $\mathrm{AB} 5$ to $\mathrm{AB} 8$. The subspiracular and ventral tubercles are slightly pronounced.

The cremaster is subquadrate (Fig. 43), similar to that of D. juno juno (Tavares et al. 2002) and ventrally flat, and each hook has a recurved apex directed toward the base (Fig. 44). The tegument has randomly arranged protuberances (Fig. 42), similar in shape to those in D. iulia alcionea (Paim et al. 2004), and is covered by a layer of wax (Figs. 35, 42). 

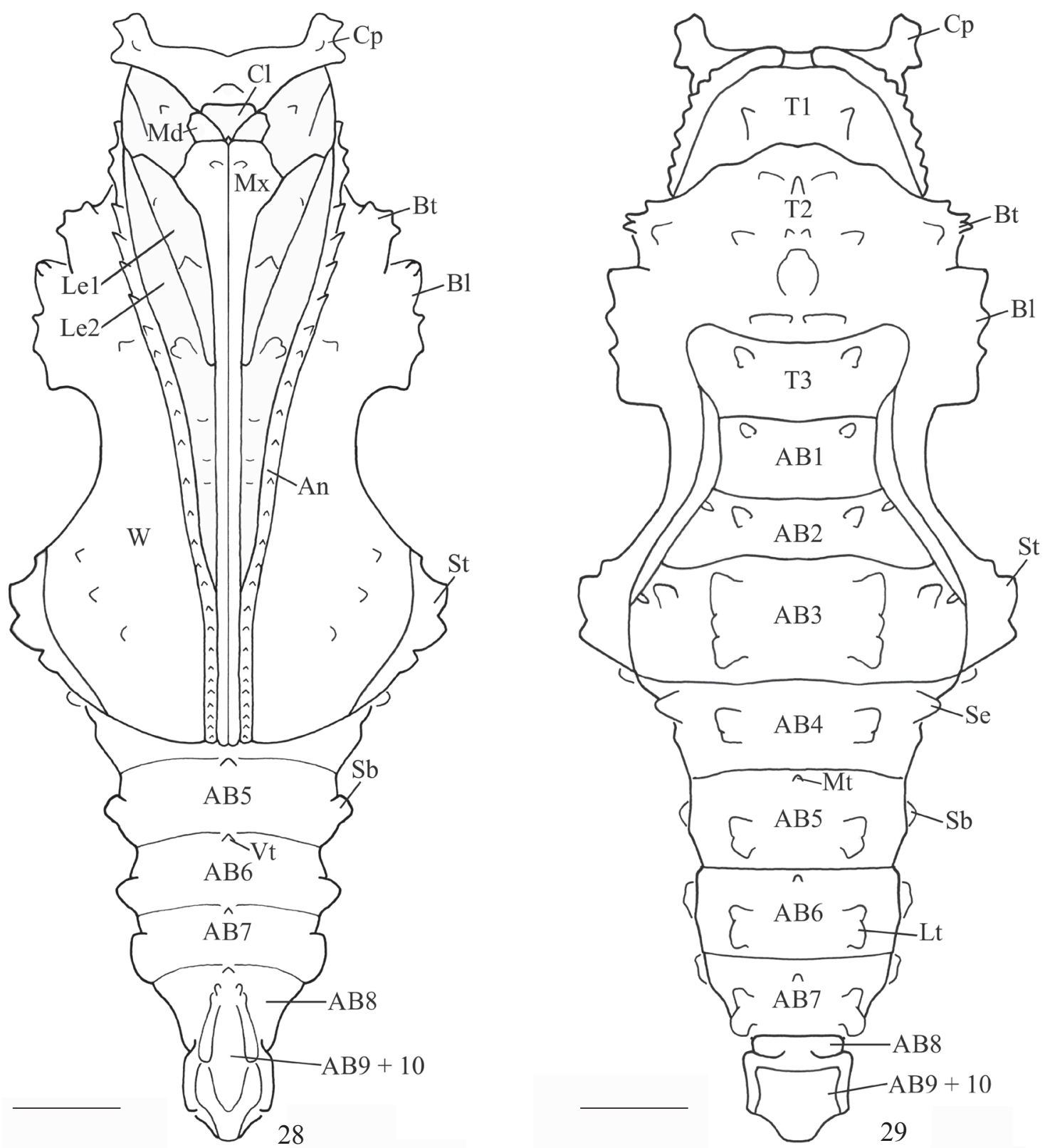

Figs. 28-29. Philaethria wernickei (Röber, 1906) pupa in ventral (28) and dorsal (29) views. AB, abdominal segment; An, antenna; Bl, longitudinal crest; Bt, basilar tubercle; Cl, clypeus; Cp, cephalic projection; Le1, prothoracic leg; Le2, mesothoracic leg; Lt, latero-dorsal tubercle; Md, mandible; Mt, medio-dorsal tubercle; Mx, maxilla; Sb, subspiracular tubercle; Se, supraspiracular tubercle; St, submarginal tubercle; T, thoracic segment; Vt, ventral tubercle; W, wing. Bars $=2 \mathrm{~mm}$.

The mesothoracic spiracle (Fig. 40) is cleft-shaped, located in the joint of this segment with the prothorax. The elliptical abdominal spiracles (Fig. 41) occur on the second through seventh segments. As is true of most Lepidoptera, that of the first abdominal segment is not visible because it is covered by the wings. The spiracles of the eighth $\mathrm{AB}$ are functionless and lack a distinct opening.

Further Remarks

Our findings lead to further questions regarding the identification of the immature stages of Philaethria species, especially those of $P$. dido and $P$. wernickei. Some differences in their shape and colour are herein addressed, as well as differences in P. dido, as described by Beebe et al. (1960) for populations in Trinidad and Tobago. In our opinion, only

Table III. Mean and standard error (SE), interval of variation (IV), and growth rates (GR) of the head-capsule width among larval instars of Philaethria wernickei (Röber, 1906), reared on Passiflora actinia Hooker.

\begin{tabular}{ccccc}
\hline & & \multicolumn{3}{c}{ Head-capsule width $(\mathrm{mm})$} \\
\cline { 3 - 5 } Instar & $\mathrm{N}$ & Mean \pm SE & IV & GR \\
\hline I & 18 & $0.776 \pm 0.008$ & $0.693-0.840$ & --- \\
II & 10 & $0.983 \pm 0.020$ & $0.924-1.036$ & 1.27 \\
III & 12 & $1.510 \pm 0.010$ & $1.444-1.596$ & 1.53 \\
IV & 8 & $2.211 \pm 0.054$ & $2.000-2.437$ & 1.46 \\
V & 5 & $3.880 \pm 0.058$ & $3.700-4.000$ & 1.75 \\
\hline
\end{tabular}



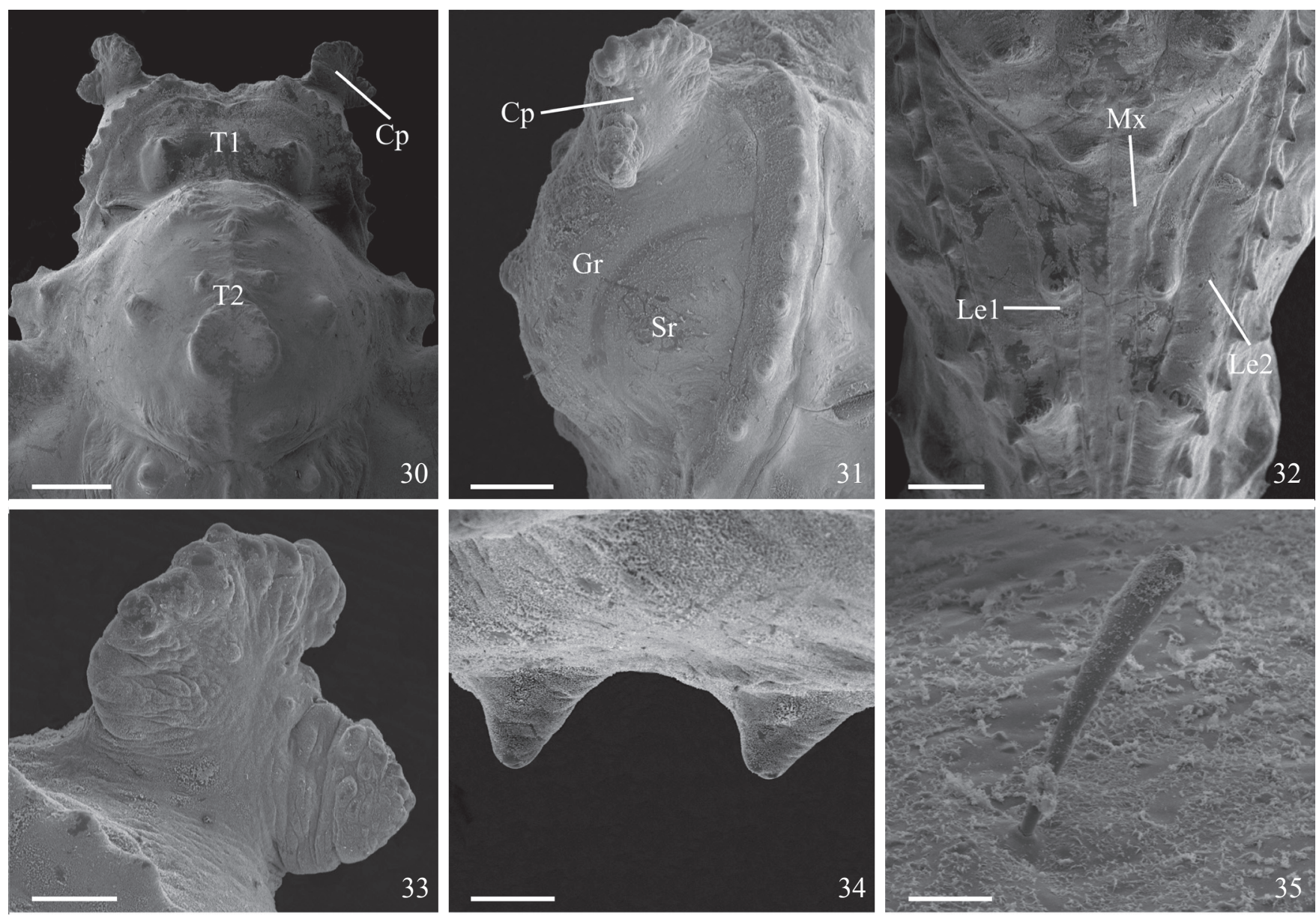

Figs. 30-35. Scanning electron micrographs of the pupa of Philaethria wernickei (Röber, 1906). 30, head and thorax, dorsal view; 31, head, lateral view; 32, head and thorax, ventral view; 33, cephalic projection, dorsal view; 34, tubercles of median portion of antenna; 35, seta from sculptured region of eye. Cp, cephalic projection; Gr, glazed stripe of eye; Le1, prothoracic leg; Le2, mesothoracic leg; Mx, proximal portion of mandible; Sr, sculptured region of eye; T, thoracic segment. Bars $=1400,600,1000,300,200$, and $30 \mu \mathrm{m}$, respectively.

when continental populations of the latter species are taken into account, will we know whether or not these differences are consistent. Several structures described herein by scanning electron microscopy were not addressed by Beebe et al. (1960). As mentioned previously, the genus is in need of revision, and $P$. dido may eventually prove to be a species complex. In addition, the immature stages of five of the seven species ascribed to it have not yet been described in detail. Furthermore, Brown \& Mielke (1972) and Brown (1981) noted differences in colour pattern between $P$. dido and P. wernickei larvae that were not corroborated by our study. Additional specimens that we reared from populations of Paraná and Minas Gerais, from which typical adults of $P$. wernickei were obtained, suggested the existence of considerable variation in the intensity and tonality of the colours herein described, even overlapping with the patterns alleged by these authors to separate the species. For example, the background colour of these specimens varied from almost white to yellowishgreen, and the extent of orange varied from the bases of the scoli to almost their entire length (with only the apex being black).

We are now carrying out an extensive survey of
Philaethria, mainly in the Atlantic rain forest region, where these species overlap in distribution. In addition to the use of a classical morphological approach, we are comparing their populations from the perspectives of molecular biology and geometric morphometry, thus searching for a more comprehensive pattern of spatial variation and stable characters to differentiate them.

Acknowledgements. The authors are grateful to Fernando Campos (UFMG), Olaf H. H. Mielke, Mirna Casagrande, and Eduardo Carneiro (UFPR) for their support in the additional collection of immature stages of $P$. wernickei in Minas Gerais and Paraná. We thank Denis S. da Silva (UFRGS), for his suggestions throughout the study, and Olaf H. H. Mielke for critical reading of the first version of the manuscript. We are also grateful to an anonymous reviewer for important suggestions that improved substantially the final version of the manuscript. Janet W. Reid revised the English text. This study was partially funded by CNPq (Proc. No. 479835/2007-1, granted to G. R. P. Moreira) and PET/SESu/MEC (granted to K. R. Barão).

\section{REFERENCES}

Antunes, F. F.; A. O. Menezes Jr.; M. Tavares \& G. R. P. Moreira. 2002. Morfologia externa dos estágios imaturos de heliconíneos neotropicais: I. Eueides isabella dianasa (Hübner, 1806). Revista Brasileira de 

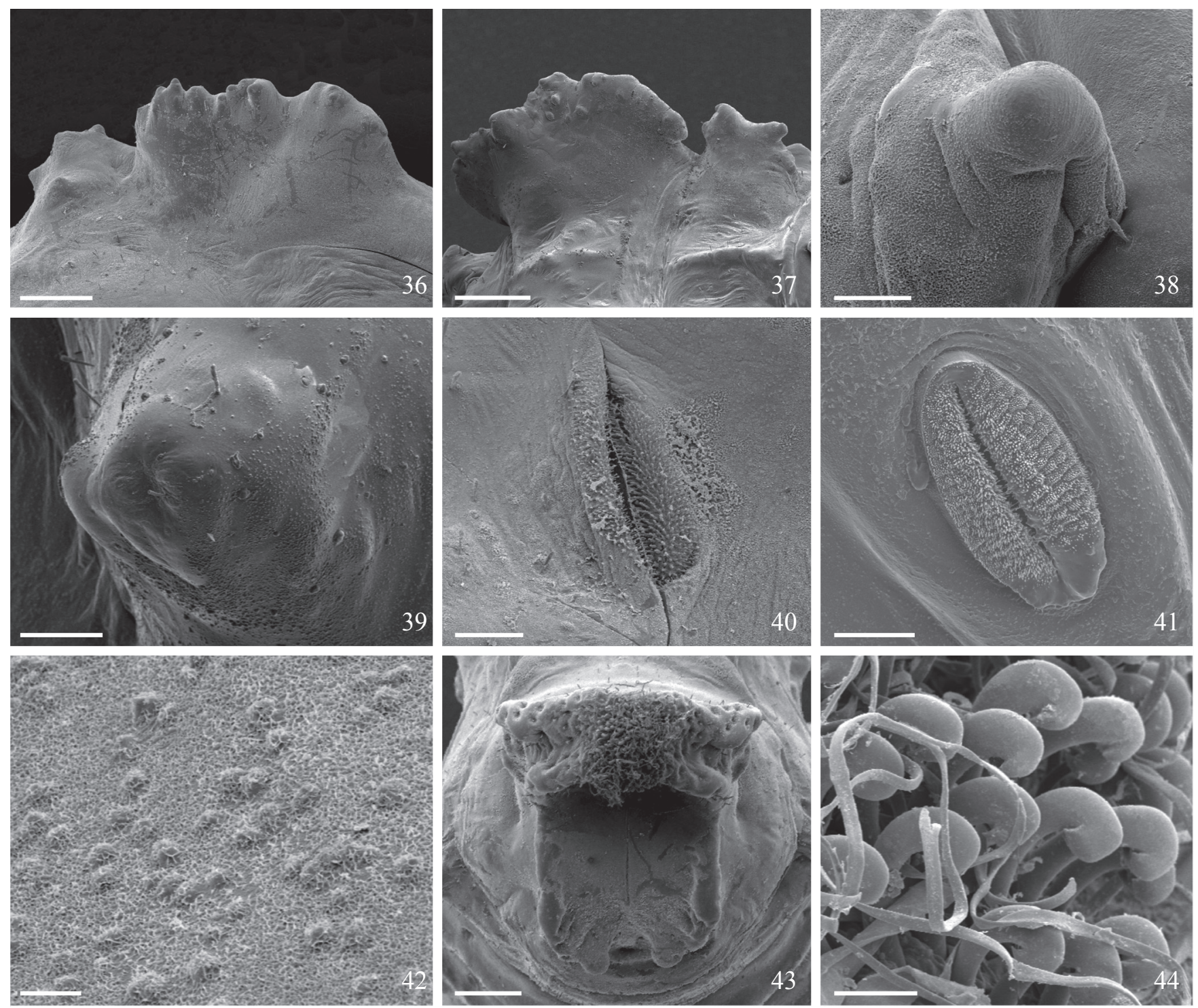

Figs. 36-44. Scanning electron micrographs of the pupa of Philaethria wernickei (Röber, 1906). 36, basilar tubercle, dorsal view; 37, latero-dorsal tubercle, lateral view; 38, median-dorsal tubercle, latero-dorsal view; 39, supraspiracular tubercle, lateral view; 40, mesothoracic spiracle; 41, spiracle of fourth abdominal segment; 42, detail of tegumentary sculpture; 43, cremaster, ventral view; 44, cremaster hooks. Bars $=800,900,100,200,200,100,10,600$, and $50 \mu \mathrm{m}$, respectively.

Entomologia 46: 601-610.

Beebe, W.; J. Crane \& H. Fleming. 1960. A comparison of eggs, larvae and pupae in fourteen species of heliconiine butterflies from Trinidad, W. I. Zoologica 45: 111-154.

Beltrán, M.; C. D. Jiggins; A.V. Z. Brower; E. Bermingham \& J. Mallet. 2007. Do pollen feeding, pupal-mating and larval gregariousness have a single origin in Heliconius butterflies? Inferences from multilocus DNA sequence data. Biological Journal of the Linnean Society 92: 221-239.

Benson, W. W.; K. S. Brown, Jr. \& L. E. Gilbert. 1975. Coevolution of plants and herbivores: passion flower butterflies. Evolution 29: 659-680.

Biezanko, C. M. \& D. Link. 1972. Nomes populares dos Lepidópteros no Rio Grande do Sul. Boletim Técnico, Universidade Federal de Santa Maria. $15 \mathrm{p}$.

Brevignon, C. 2002. Description d'un nouveau Philaethria provenant de Guyane Française et notes sur sa biologie. Lambillionea 102: 469 473.

Brower, A. V. Z. 1994. Rapid morphological radiation and convergence among races of the butterfly Heliconius erato inferred from patterns of mitochondrial DNA evolution. Proceedings of the National Academy of Sciences of the United States of America 91: 6491-6495.

Brown, K. S. Jr. 1981. The biology of Heliconius and related genera. Annual Review of Entomology 26: 427-456.

Brown, K. S. Jr. \& O. H. H. Mielke. 1972. The Heliconians of Brazil (Lepidoptera: Nymphalidae). Part II. Introduction and general comments, with a supplementary revision of the tribe. Zoologica 57: 1-40.

Constantino, L. M. 1999. Nuevas especies, subespecies y un nuevo genero de Ropaloceros del occidente de Colombia. Boletín Científico Museo de Historia Natural Universidad de Caldas 3: 57-68.

Dell'Erba, R.; L. A. Kaminski \& G. R. P. Moreira. 2005. O estágio de ovo dos Heliconiini (Lepidoptera, Nymphalidae) do Rio Grande do Sul, Brasil. Iheringia, Série Zoologia 95: 29-46.

Downey, J. C. \& A. C. Allyn Jr. 1981. Chorionic sculpturing in eggs of Lycaenidae. Part I. Bulletin of Allyn Museum 61: 1-29.

Emsley, M. G. 1963. A morphological study of imagine Heliconiinae (Lepidoptera: Nymphalidae) with a consideration of the evolutionary relationships within the group. Zoologica 48: 85-130.

Fleming, H. 1960. The first instar larvae of the Heliconiinae (butterflies) of Trinidad, W. I. Zoologica 45: 91-110.

Harvey, D. J. 1991. Higher classification of the Nymphalidae. Appendix B, 
p. 255-273. In: H. F. Nijhout (ed.). The Development and Evolution of Butterfly Wing Patterns. Washington, Smithsonian Institution, xvi +297 p.

Kaminski, L. A.; M. Tavares; C. G. Ferro \& G. R. P. Moreira. 2002. Morfologia externa dos estágios imaturos dos heliconíneos neotropicais. III. Heliconius erato phyllis (Fabricius) (Lepidoptera, Nymphalidae, Heliconiinae). Revista Brasileira de Zoologia 19: 977-993.

Kaminski, L. A.; R. Dell'Erba \& G. R. P. Moreira. 2008. Morfologia externa dos estágios imaturos de heliconíneos neotropicais. VI. Dione moneta moneta Hübner (Lepidoptera, Nymphalidae, Heliconiinae). Revista Brasileira de Entomologia 52: 13-23.

Kitching, I. J. 1984. The use of larval chaetotaxy in butterfly systematics, with special reference to the Danaini (Lepidoptera: Nymphalidae). Systematic Entomology 9: 49-61.

Lamas, G. 2004. Checklist: Part 4A. Hesperioidea - Papilionoidea. In: J. B. Heppner (ed.). Atlas of Neotropical Lepidoptera. Vol. 5A. Gainesville, Association for Tropical Lepidoptera, Scientific Publishers, 428 p.

Miller, J. S. 1991. Cladistics and classification of the Notodontidae (Lepidoptera: Noctuoidea) based on larval and adult morphology. Bulletin of the American Museum of Natural History 204: 1-230.

Mosher, E. 1916. A classification of the Lepidoptera based on characters of the pupa. Bulletin of the Illinois State Laboratory of Natural History 12: $1-165$.

Paim, A. C.; L. A. Kaminski \& G. R. P. Moreira. 2004. Morfologia externa dos estágios imaturos de heliconíneos neotropicais. IV. Dryas iulia alcionea (Lepidoptera, Nymphalidae, Heliconiinae). Iheringia, Série Zoologia 94: 25-35.

Penz, C. M. 1999. Higher level phylogeny for passion-vine butterflies (Nymphalidae, Heliconiinae) based on early stage and adult morphology. Zoological Journal of the Linnean Society 127: 277-344.

Peterson, A. 1962. Larvae of Insects. An Introduction to Nearctic Species. Part I Lepidoptera and Plant Infesting Hymenoptera. Ann Arbor,
Edwards Brothers Inc., 315 p.

Röber, J. 1906. Neue Schmetterling. Societas Entomologica 20: 177-178.

Salazar, J. A. 1991. Descripción de una nueva especie de Philaethria Billberg,

1820 para el occidente de Colombia (Lepidoptera: Nymphalidae: Heliconiinae). Shilap Revista de Lepidopterologia 19: 273-279.

Seitz, A. 1913. Heliconiinae, p. 375-402, pls. 72-80, 84-85. In: Seitz, A 1907-1924. Die Gross-Schmetterling der Erde 5, Stuttgart, Alfred Kernen Verlag, $1141 \mathrm{p}$.

Silva, D. S.; R. Dell'Erba; L. A. Kaminski \& G. R. P. Moreira. 2006. Morfologia externa dos estágios imaturos de heliconíneos neotropicais: V. Agraulis vanillae maculosa (Lepidoptera, Nymphalidae, Heliconiinae). Iheringia, Série Zoologia 96: 219-228.

Silva, D. S.; L. A. Kaminski; R. Dell'Erba \& G. R. P. Moreira. 2008. Morfologia externa dos estágios imaturos de heliconíneos neotropicais: VII. Dryadula phaetusa (Linnaeus) (Lepidoptera, Nymphalidae, Heliconiinae). Revista Brasileira de Entomologia 52: 500-509.

Snedecor, G. W. \& W. G. Cochran. 1980. Statistical Methods. Ames, Iowa State University, $507 \mathrm{p}$.

Stehr, F. W. 1987. Order Lepidoptera, p. 288-305. In: F. W. Stehr, (ed.). Immature Insects. Vol. 1. Dubuque, Kendall/ Hunt Publishing Company, 975 p.

Suomalainen, E. \& K. S. Brown, Jr. 1984. Chromosome number variation within Philaethria butterflies (Lepidoptera: Nymphalidae, Heliconiini) Chromossoma 90: 170-176.

Tavares, M.; L. A. Kaminski \& G. R. P. Moreira. 2002. Morfologia externa dos estágios imaturos dos heliconíneos neotropicais. II. Dione juno juno (Cramer) (Lepidoptera, Nymphalidae, Heliconiinae). Revista Brasileira de Zoologia 19: 961-976.

Young, A. M. 1974. Further observations on the natural history of Philaethria dido dido (Lepidoptera: Nymphalidae: Heliconiinae). Journal of the New York Entomological Society 82: $30-41$. 